\title{
Unusual presentation of dengue haemorrhagic fever in a neonate: Fluid leak and shock on day 1 of illness
}

\author{
Prathibha Arsakularatna ${ }^{1}$, Kalaichchelvi Guruparan ${ }^{1}$, Thirukkumaran Thirusun ${ }^{1}$ *Sathika \\ Amarasekara $^{2}$, Medha Weerasekera ${ }^{3}$
}

Sri Lanka Journal of Child Health, 2021; 50(1): 156-158

DOI: http://dx.doi.org/10.4038/sljch.v50i1.9419

(Key words; Dengue shock syndrome, vertical transmission, neonate)

\section{Introduction}

Dengue causes a spectrum of manifestations ranging from non-specific acute fever, dengue fever (DF), dengue haemorrhagic fever (DHF) and dengue shock syndrome (DSS) ${ }^{1,2}$. Vertical transmission of the virus leading to neonatal dengue fever is a well-known entity and may result in any manifestation out of the above spectrum. Furthermore, maternal infection near term may cause severe neonatal disease including DHF and $\mathrm{DSS}^{3-5}$. We report a neonate who developed DSS on the very first day of the fever.

\section{Case report}

A term baby boy was admitted to the special care baby unit just after birth as his mother was in medical intensive care unit due to DHF. The pregnancy was uneventful and the baby weighed $3200 \mathrm{~g}$ at birth. He was clinically well up to 2 days of age, was on full feeds and cot care. Complete blood count was normal and dengue NS1 and IgM were negative on day 1 of age. Dengue IgG was positive as expected due to trans-placental passage. On the third day of life, he developed acute high fever of $101^{0} \mathrm{~F}$ with flushed skin and poor activity. Three hours after the onset of fever, baby was grunting and was in shock with cold extremities. Abdominal sonography showed evidence of leakage with free fluid in the sub-hepatic space and pelvis. Hence baby was considered to be in the critical phase of DHF and managed accordingly. During the next 6 hours, baby developed apnoeic episodes, tonic convulsions and needed elective intubation to avoid a catastrophe. Repeat investigations sent at the onset of fever showed a drop in platelets and a positive NS1Ag. On day two of illness baby's platelet count was $39,000 / \mu 1$ with progressive reduction of haematocrit by $16.5 \%$, along with persistent pulse pressure less than 20 . (Table 1)

Table 1: Serial full blood counts

\begin{tabular}{|c|c|c|c|c|c|c|c|c|c|c|c|}
\hline Age of baby & Day 1 & $\begin{array}{c}\text { Day } 3 \\
\text { am }\end{array}$ & $\begin{array}{c}\text { Day } 3 \\
\text { pm }\end{array}$ & $\begin{array}{c}\text { Day4 } \\
\text { am }\end{array}$ & $\begin{array}{c}\text { Day } 4 \\
\text { pm }\end{array}$ & $\begin{array}{c}\text { Day } 5 \\
\text { am }\end{array}$ & $\begin{array}{c}\text { Day } 5 \\
\text { pm }\end{array}$ & $\begin{array}{c}\text { Day } 6 \\
\text { am }\end{array}$ & $\begin{array}{c}\text { Day } 6 \\
\text { pm }\end{array}$ & Day 7 & Day 11 \\
\hline $\mathrm{WBC} / \mathrm{mm}^{-3}$ & 27,020 & 9,900 & 10,200 & 13,300 & 10,290 & 10,900 & 10,500 & 12,300 & 14,100 & 14,900 & 18.700 \\
\hline $\mathrm{N} \%$ & 78.0 & 82.2 & 84.1 & 78.0 & 78.0 & 57.0 & 69.0 & 58.0 & 30.3 & 39.0 & 43.5 \\
\hline $\mathrm{L} \%$ & 14.0 & 09.2 & 08.3 & 18.0 & 14.0 & 25.0 & 26.0 & 37.4 & 46.1 & 50.0 & 43.8 \\
\hline $\mathrm{Hb} \mathrm{g/dl}$ & 20.4 & 21.4 & 21.1 & 18.5 & 18.0 & 19.9 & 20.1 & 19.2 & 18.2 & 18.3 & 17.8 \\
\hline HCT \% & 61.3 & 63.0 & 63.0 & 55.4 & 52.6 & 59.0 & 58.2 & 56.2 & 51.7 & 54.1 & 52.2 \\
\hline $\mathrm{PC} / \mathrm{mm}^{3}$ & 214,000 & 165,000 & 95,000 & 55,000 & 39,000 & 26,000 & 6,000 & 10,000 & 6,000 & 17,000 & 23,000 \\
\hline
\end{tabular}

WBC: white blood cell, $N$ : neutrophils, L: lymphocytes, Hb: haemoglobin, HCT: haematocrit, PC: platelet count

${ }^{1}$ Registrar in Paediatrics, ${ }^{2}$ Senior Registrar in Neonatology, ${ }^{3}$ Consultant Neonatologist, Sri Jayewardenepura General Hospital, Nugegoda, Sri Lanka

*Correspondence: sathika2.ama@gmail.com

https://orcid.org/0000-0002-0018-4597

(Received on 27 March 2020: Accepted after revision on 22 May 2020)

The authors declare that there are no conflicts of interest

Personal funding was used for the project.

Open Access Article published under the Creative

Commons Attribution CC-BY (C) (i) License
His activated partial thromboplastin time (APTT) was 74 with the international normalised ratio (INR) 1.32. Hence baby was suspected to have concealed bleeding and $5 \mathrm{ml} / \mathrm{kg}$ of packed red cells was transfused. Aspartate aminotransferase level was $16 \mathrm{U} / \mathrm{L}$ on first day of fever and was increased to $308 \mathrm{U} / \mathrm{L}$ on day 3 of illness. Cranial ultrasonography excluded intracranial haemorrhage. Septic screen was negative. He was managed according to the national guideline on management of DHF in children and adolescents. The critical phase lasted almost for 72 hours. The diuresis and normalization of haematocrit were noted from the day 4 of illness onwards. Slow rise of platelets was detected from day 6 of illness. Baby was discharged home on day 11 of life. 


\section{Discussion}

During dengue epidemics, increasing numbers of pregnant women are at risk of dengue infection ${ }^{6}$. Complications of dengue infection during pregnancy are preterm delivery, intra-uterine death, miscarriage and acute fetal distress during labour ${ }^{2,3,7,8}$. Generally, secondary infection with dengue virus is known to be more serious ${ }^{6}$. However, when primary infection occurs in late pregnancy and delivery takes place at the height of viraemia, both mother and newborn are at risk of developing life-threatening complications ${ }^{2,6}$.

Manifestations of vertically transmitted dengue infection are diverse in neonates. Newborn with DF may remain asymptomatic ${ }^{9}$ Fever, thrombocytopenia, hepatomegaly, elevated transaminases, DHF and DSS have been reported in the literature $e^{2,6,8,10}$. In severely affected babies, bleeding manifestations, including cerebral haemorrhages, can occur ${ }^{3,11}$. Though perinatal transmission of DF is being reported more frequently from different regions, no consensus has been reached regarding management of neonatal dengue $^{10}$. Fever onset in newborns ranges from 1 to 11 days after birth with a mean of 4 days and may last for 1-5 days ${ }^{6,12}$. Our patient had fever onset on day 3 of life. Generally, the commonest symptoms reported in newborns with vertically transmitted dengue are fever and thrombocytopenia ${ }^{2,6}$. Cases with DHF and DSS are rare in the literature. Time of onset of the critical phase in neonates and infants is generally similar to that in older children. In contrast, our patient developed critical phase on day 1 of fever and required ventilation within three hours of onset of fever.

Confirmation of dengue infection can be made by virus isolation, detection of viral RNA by polymerase chain reaction (PCR) and NS1 antigen $^{7,8}$. Samples should be taken for dengue viral detection within the first four to five days during the febrile phase ${ }^{7,10}$. IgM levels can be detected from 3-5 days, peak around two weeks, and decline to undetectable levels by 2-3 months ${ }^{7,10}$. IgG appears in low levels in the beginning after $\operatorname{IgM}^{7,10}$. Blood PCR aids identification of the dengue serotype ${ }^{2}$. In our patient, NS1 antigen was positive on the first day of illness.

Babies born to mothers with DF in late pregnancy should be closely monitored for warning signs well into the second week of life before being considered for discharge, especially during epidemics $^{2,6}$. Newborns diagnosed with dengue fever should be managed according to the local guidelines based on their manifestations. Antidengue activity has been detected in human milk and colostrum provides protection against dengue infection in breastfed babies ${ }^{5}$.

\section{References}

1. Ministry of Health, Sri Lanka in collaboration with the Sri Lanka College of Paediatricians. National Guidelines on management of DF and DHF in children and adolescents: revised and expanded edition, December 2012. Available from: http://www.epid.gov.lk/web/images/pdf/P ublication/gmdfca12.pdf

2. Maroun SL, Marliere RC, Barcellus RC, Barbosa CN, Ramos JR, Moreira ME. Case report: vertical dengue infection. Journal of Pediatrics (Rio J) 2008; 84(6):556-9.

https://doi.org/10.1590/S00217557200800 0700014

3. Basurko C, Carles G, Youssef M, Guindi WE: Maternal and fetal consequences of dengue fever during pregnancy. European Journal of Obstetrics and Gynecology and Reproductive Biology 2009; 147(1): 2932.

https://doi.org/10.1016/j.ejogrb.2009.06.0 28

PMid: 19632027

4. Toovey S, Van Gompel A. Dengue fever and pregnancy a review and comment. Travel Medicine and Infectious Disease 2007; 5:183-8. https://doi.org/10.1016/j.tmaid.2006.11.00 2

PMid: 17448946

5. Jain A, Chaturvedi UC. Dengue in infants: an overview. FEMS Immunology and Medical Microbiology 2010; 59(2): 11930 .

https://doi.org/10.1111/j.1574695X.2010.0 0670.x

PMid: 20402771 PMCid: PMC7110389

6. Mitra N, Kannan N, Kavita G, Senthil V. Neonatal Dengue. Pediatric Oncall Journal 2012; 9: 68-9.

https://doi.org/10.7199/ped.oncall.2012.44

7. Yin $\mathrm{X}$, Zhong $\mathrm{X}$, Pan S. Vertical transmission of dengue infection: the first putative case reported in China. Revista do Instituto de Medicina Tropical de São Paulo 2016; 58:90. 
https://doi.org/10.1590/s1678-

9946201658090

PMid: 27982356 PMCid: PMC5147720

8. Thomas J, Thomas P, George CR. Neonatal dengue. International Journal of Contemporary Pediatrics 2017; 4(6):2234-6.

https://doi.org/10.18203/23493291.ijcp201 74765

9. Grunnill M, Boots M. How important is vertical transmission of dengue viruses by mosquitoes (diptera: culicidae)? Journal of Medical Entomology 2016; 53(1):1-19. https://doi.org/10.1093/jme/tjv168 PMid: 26545718

10. Ghosh A, Roy S, Uttam KG. Two cases of severe neonatal dengue fever during an outbreak in Kolkata city. Indian Journal of Case Reports 2017; Published online 06 May.
11. Thomas J, Thomas P, George CR. Neonatal dengue. International Journal of Contemporary Pediatrics 2017; 4: 2234-6. https://doi.org/10.18203/23493291.ijcp201 74765

12. Sirinavin $S, \quad$ Nuntnarumit $P$, Supapannachart S, Boonkasidecha S, Techasaensiri C, Yoksarn S. Vertical dengue infection: case reports and review. Pediatric Infectious Disease Journal 2004; 23: 1042-7.

https://doi.org/10.1097/01.inf.0000143644 $.95692 .0 \mathrm{e}$

PMid: 15545860 